\title{
A family study of spina bifida and anencephalus in Belfast, Northern Ireland (1964 to 1968)
}

\author{
N C NEVIN AND W P JOHNSTON \\ From the Department of Medical Genetics, The Queen's University of Belfast, \\ Belfast, Northern Ireland
}

SUMMARY The parents of 226 of the 360 patients with anencephalus or spina bifida or both, born in Belfast 1964 to 1968 , were visited to document the occurrence of these malformations among other relatives. The proportions of sibs with anencephalus and spina bifida were $10.42 \%$ for spina bifida index patients and $6.47 \%$ for anencephalus. For patients born after the index patients, the proportions were $12.19 \%$ and $6.35 \%$, respectively. The overall incidence of either malformation among sibs was $8 \cdot 87 \%$. This estimate is higher than the 4 to $5 \%$ commonly reported and is probably related to the specific background of the Northern Ireland population, which is known to have the highest incidence of CNS malformations in the United Kingdom. The substantial size of this risk indicates the importance of amniocentesis for monitoring subsequent pregnancies of women who have had one child with a CNS malformation.

This family study is based on patients with spina bifida and anencephalus, born between the years 1964 and 1968, inclusive, in Belfast, Northern Ireland. Details of the area, method of ascertainment, and biosocial factors are given in Elwood and Nevin. ${ }^{12}$ The total births were 41351 , of which 360 patients had a central nervous system (CNS) malformation: 151 had anencephalus; 185 had spina bifida; and 24 had anencephalus with spina bifida. The incidence of anencephalus, which includes the group having anencephalus with spina bifida, was $4 \cdot 2$, and of spina bifida 4.5 per 1000 total births, giving an overall incidence of these two malformations of 8.7 per 1000 total births. This incidence is the highest so far reported and exceeds that of South Wales, another high incidence area in the United Kingdom, where the incidence of the two malformations is $4 \cdot 1$ and $3 \cdot 5$, respectively. ${ }^{3}$

\section{Methods}

For a study of familial aggregation, only cases ascertained in Belfast for 1964 to 1968 were included. However, owing to the 'troubles' in Northern Ireland and the increased movement of population, it was only possible to trace 226 of the $360(62.8 \%)$ of the original cohort. Of the 185 (76 male, 109 female) patients with spina bifida, 134 (61 male and Received for publication 4 October 1979
73 female) were contacted, and of the 175 (46 male and 129 female) with anencephalus or anencephalus with spina bifida, 92 ( 25 male and 67 female) were traced. The parents of the index patients were visited. Family histories were obtained and in many instances were confirmed or supplemented by visits to other relatives. The family history included information on sibs, parents, grandparents, aunts, and uncles. Affected or possibly affected relatives were documented from hospital records or death certificates or both. Summary family histories are given in appendix 1 .

\section{Results}

RECURRENCE RISKS FOR SIBS

The outcome of all the pregnancies of the mothers of the index patients are listed in table 1 . They had a total of 874 pregnancies yielding 710 sibs, of whom $63(8.87 \%)$ had anencephalus or spina bifida. The percentage of affected sibs was higher $(10.42 \%)$ when the index case had spina bifida than when it had anencephalus $(6 \cdot 47 \%)$. The rate among previous sibs was 35 in $420(8.33 \%)$ and the rate among subsequent sibs was 28 in $290(9.66 \%)$. There were 176 spontaneous abortions, a rate of $25 \cdot 2 \%$.

\section{Spina bifida}

The findings in the sibs of the spina bifida index 
TABLE 1 Outcome of pregnancies of women having at least one child with a CNS malformation, Belfast 1964-1968

\begin{tabular}{|c|c|c|c|}
\hline & \multicolumn{2}{|l|}{ Index patient } & \multirow[t]{2}{*}{ Total } \\
\hline & Anencephalus & Spina bifida & \\
\hline No of index patients & 92 & 134 & 226 \\
\hline No of singleton sibs & 264 & 419 & 683 \\
\hline No of twin pregnancies & 7 & $8+$ & 15 \\
\hline Total No of sibs & 278 & 432 & 710 \\
\hline No of anencephalus or & & & \\
\hline $\begin{array}{l}\text { spina bifida sibs } \\
\text { Affected sibs }(\%)\end{array}$ & $\begin{array}{l}18 \\
6 \cdot 47\end{array}$ & $\begin{array}{l}45 \\
10 \cdot 42\end{array}$ & $\begin{array}{l}63 \\
8.87\end{array}$ \\
\hline No of spontaneous abortions & $68^{*}$ & 108 & 176 \\
\hline$\%$ of pregnancies & $25 \cdot 09$ & $25 \cdot 29$ & $25 \cdot 21$ \\
\hline
\end{tabular}

*One was a twin pregnancy. †Index patient in three sets of twins.

patients are shown in table 2 . Of 246 brothers, 15 $(6 \cdot 10 \%)$ had spina bifida, and seven $(2 \cdot 85 \%)$ had anencephalus. Of 186 sisters, $18(9.68 \%)$ had spina bifida, and five $(2.69 \%)$ had anencephalus. The total incidence of either malformation was $8.94 \%$ in brothers and $12.36 \%$ in sisters; the total incidence in sibs of either sex was $10.42 \%$.

Analysis by sex of the index patient shows that for males, 28 of $209(13.40 \%)$ sibs, and for females, 17 of $223(7.62 \%)$ sibs were affected. Among sibs born before the index patient, the proportion of sibs affected was 25 of $268(9.33 \%)$ and among the sibs born after the index patient the proportion of sibs affected was 20 of $164(12 \cdot 19 \%)$. There were 31 families in which the index patient was the result of $\frac{\mathbb{\Phi}}{\stackrel{D}{(}}$ the first pregnancy; among the subsequent 46 sibs, $\stackrel{?}{\rightarrow}$ four $(8.69 \%)$ had a CNS malformation. In families $\overrightarrow{\vec{F}}$ in which the index patient was not the first con- 0 ception, of 386 subsequent sibs $41(10.62 \%)$ had a CNS malformation. There is no significant differ- $\bar{\omega}$ ence in the percentage of sibs affected in these $\overrightarrow{\mathbb{D}}$ groups $\left(\chi^{2}=0.02 ; 0.9>p>0.8\right)$.

\section{Anencephalus}

The findings in the sibs of index patients with $\vec{\omega}$ anencephalus are shown in table 3 . There were 92 o index patients, 25 males and 67 females. Of 149 brothers, seven $(4.70 \%)$ had spina bifida and four $(2.68 \%)$ had anencephalus. Of 129 sisters, two $(1.55 \%)$ had spina bifida and five $(3.88 \%)$ had $\omega$ anencephalus. The total incidence of either mal- $\mathrm{\omega}$ formation was $7 \cdot 38 \%$ in brothers and $4.70 \%$ in 응 sisters, and the total incidence in sibs of either sex was $6.47 \%$. One older sister of a female index $\vec{c}$ patient had congenital hydrocephalus.

On analysis by sex of index patient, eight of 76 $(10.53 \%)$ of sibs of male index patients and 10 of $202(4.95 \%)$ of sibs of female index patients were. affected. Among the sibs born before index patients, 10 of $152(6.58 \%)$ were affected, and among those born after the index patient eight of $126(6.35 \%)$. There were 23 families in which the index patient was the result of the first pregnancy: among the $\mathbb{Q}$

TABLE 2 Brothers and sisters of index patients with spina bifida distinguishing those born before and those born after index patients

\begin{tabular}{|c|c|c|c|c|c|c|c|c|c|c|c|c|c|}
\hline \multicolumn{2}{|c|}{ Index patient } & \multicolumn{6}{|c|}{ Brothers } & \multicolumn{6}{|c|}{ Sisters } \\
\hline & & \multicolumn{2}{|l|}{ Older } & \multicolumn{2}{|c|}{ Younger } & \multicolumn{2}{|l|}{ Total } & \multicolumn{2}{|l|}{ Older } & \multicolumn{2}{|c|}{ Younger } & \multicolumn{2}{|l|}{ Total } \\
\hline & & Total & Affected & Total & Affected & Total & Affected & Total & Affected & Total & Affected & Total & Affected \\
\hline Male & 61 & 71 & $\begin{array}{ll}3 & \mathrm{~A} \\
1 & \mathrm{SB}\end{array}$ & 47 & $\begin{array}{ll}2 & \mathrm{~A} \\
5 & \mathrm{SB}\end{array}$ & 118 & $\begin{array}{ll}5 & \mathrm{~A} \\
6 & \mathrm{SB}\end{array}$ & 54 & $\begin{array}{ll}3 & \mathrm{~A} \\
6 & \mathrm{SB}\end{array}$ & 37 & $\begin{array}{l}2 \mathrm{~A} \\
6 \mathrm{SB}\end{array}$ & 91 & $\begin{aligned} 5 \mathrm{~A} \\
12 \mathrm{SB}\end{aligned}$ \\
\hline Female & 73 & 87 & $\begin{array}{ll}1 & \mathrm{~A} \\
6 & \mathrm{SB}\end{array}$ & 41 & $\begin{array}{ll}1 & \mathrm{~A} \\
3 & \mathrm{SB}\end{array}$ & 128 & $\begin{array}{l}2 \mathrm{~A} \\
9 \mathrm{SB}\end{array}$ & 56 & $\begin{array}{ll}0 & \mathrm{~A} \\
5 & \mathrm{SB}\end{array}$ & 39 & $\begin{array}{ll}0 & \mathrm{~A} \\
1 & \mathrm{SB}\end{array}$ & 95 & $\begin{array}{l}0 \mathrm{~A} \\
6 \mathrm{SB}\end{array}$ \\
\hline Total & 134 & 158 & $\begin{array}{l}4 \mathrm{~A} \\
7 \mathrm{SB}\end{array}$ & 88 & $\begin{array}{ll}3 & \mathrm{~A} \\
8 & \mathrm{SB}\end{array}$ & 246 & $\begin{array}{r}7 \mathrm{~A} \\
15 \mathrm{SB}\end{array}$ & 110 & $\begin{aligned} 3 \mathrm{~A} \\
11 \mathrm{SB}\end{aligned}$ & 76 & $\begin{array}{ll}2 & \mathrm{~A} \\
7 & \mathrm{SB}\end{array}$ & 186 & $\begin{array}{r}5 \mathrm{~A} \\
18 \mathrm{SB}\end{array}$ \\
\hline
\end{tabular}

TABLE 3 Brothers and sisters of index patients with anencephalus distinguishing those born before and after index patients

\begin{tabular}{|c|c|c|c|c|c|c|c|c|c|c|c|c|c|}
\hline \multicolumn{2}{|c|}{ Index patient } & \multicolumn{6}{|c|}{ Brothers } & \multicolumn{6}{|c|}{ Sisters } \\
\hline & & \multicolumn{2}{|l|}{ Older } & \multicolumn{2}{|c|}{ Younger } & \multicolumn{2}{|l|}{ Total } & \multicolumn{2}{|l|}{ Older } & \multicolumn{2}{|c|}{ Younger } & \multicolumn{2}{|l|}{ Total } \\
\hline & & Total & Affected & Total & Affected & Total & Affected & Total & Affected & Total & Affected & Total & Affected \\
\hline Male & 25 & 21 & $\begin{array}{ll}0 & \mathrm{~A} \\
1 & \mathrm{SB}\end{array}$ & 16 & $\begin{array}{ll}1 & \mathrm{~A} \\
2 \mathrm{SB}\end{array}$ & 37 & $\begin{array}{ll}1 & \mathrm{~A} \\
3 & \mathrm{SB}\end{array}$ & 21 & $\begin{array}{cc}3 & \mathrm{~A} \\
\mathbf{0} & \mathrm{SB}\end{array}$ & 18 & $\begin{array}{ll}0 & A \\
1 & S B\end{array}$ & 39 & $\begin{array}{l}3 \mathrm{~A} \\
1 \mathrm{SB}\end{array}$ \\
\hline Female & 67 & 56 & $\begin{array}{ll}2 & \mathrm{~A} \\
2 & \mathrm{SB}\end{array}$ & 56 & $\begin{array}{ll}1 \mathrm{~A} \\
2 \mathrm{SB}\end{array}$ & 112 & $\begin{array}{ll}3 \mathrm{~A} \\
4 \mathrm{SB}\end{array}$ & 54 & $\begin{array}{cc}1 & \mathrm{~A} \\
1 & \mathrm{SB} \\
1 \mathrm{H}\end{array}$ & 36 & $\begin{array}{ll}1 & \mathrm{~A} \\
0 & \mathrm{SB}\end{array}$ & 90 & $\begin{array}{ll}2 & \mathrm{~A} \\
1 & \mathrm{SB} \\
1 & \mathrm{H}\end{array}$ \\
\hline Total & 92 & 77 & $\begin{array}{ll}2 & \mathrm{~A} \\
3 & \mathrm{SB}\end{array}$ & 72 & $\begin{array}{ll}2 & \mathrm{~A} \\
4 & \mathrm{SB}\end{array}$ & 149 & $\begin{array}{l}4 \mathrm{~A} \\
7 \mathrm{SB}\end{array}$ & 75 & $\begin{array}{ll}4 & \mathrm{~A} \\
1 & \mathrm{SB} \\
1 & \mathrm{H}\end{array}$ & 54 & $\begin{array}{ll}1 & \mathrm{~A} \\
1 & \mathrm{SB}\end{array}$ & 129 & $\begin{array}{ll}5 & \mathrm{~A} \\
2 & \mathrm{SB} \\
1 & \mathrm{H}\end{array}$ \\
\hline
\end{tabular}


subsequent 51 sibs, three had a CNS malformation $(3.88 \%)$. In the families in which the index patient was not the first conception, of 227 sibs $15(6 \cdot 61 \%)$ had a CNS malformation. There is no significant difference in the percentage of sibs affected in these groups $\left(\chi^{2}=0.02 ; 0 \cdot 9>p>0 \cdot 8\right)$.

\section{RECURRENCE RISKS FOR FIRST COUSINS}

The findings in cousins are summarised in table 4 . A comparison is made with the numbers of CNS malformations expected if the incidence had been that found in the general population for the area. Among 2293 cousins of index patients with spina bifida, 13 had a CNS malformation, whereas 20 would have been expected. It was only in the case of spina bifida among cousins that the number affected (11) approached the number expected (10). The rate for maternal cousins was higher ( 7.67 per 1000$)$ than for paternal cousins (3.57 per 1000). Of 1698 cousins of index patients with anencephalus, 15 would have been expected to have a CNS malformation and 13 were found to be affected. The rate for maternal cousins and for paternal cousins were similar, $7 \cdot 50$ and $7 \cdot 80$ per 1000 , respectively. The overall incidence of CNS malformations among cousins was 6.51 per 1000 . For paternal cousins 11 in 2017 (5.45 per 1000), and for maternal cousins 15 in 1974 (7.60 per 1000) were affected.

TABLE 4 Cousins of index patients showing number with spina bifida and anencephalus

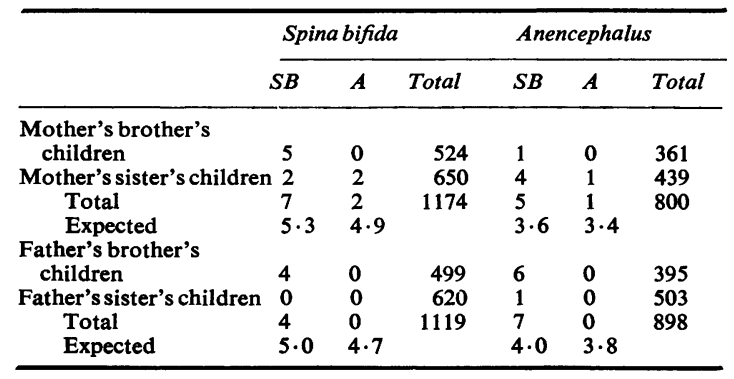

TABLE 5 Uncles and aunts of index patients showing number with spina bifida and anencephalus

\begin{tabular}{|c|c|c|c|c|c|c|}
\hline & \multicolumn{3}{|c|}{ Spina bifida } & \multicolumn{3}{|c|}{ Anencephalus } \\
\hline & $S B$ & $A$ & Total & $S B$ & $\boldsymbol{A}$ & Total \\
\hline \multicolumn{7}{|l|}{ Maternal } \\
\hline Uncles & 2 & 0 & 314 & 0 & 0 & 210 \\
\hline Aunts & 2 & 0 & 299 & 1 & 0 & 211 \\
\hline \multicolumn{7}{|l|}{ Paternal } \\
\hline Uncles & 1 & 0 & 278 & 1 & 0 & 205 \\
\hline Aunts & 2 & 0 & 300 & 2 & 0 & 206 \\
\hline Total & 7 & 0 & 1191 & 4 & 0 & 832 \\
\hline
\end{tabular}

\section{RECURRENCE RISKS FOR}

\section{SECOND DEGREE RELATIVES}

Information on aunts and uncles was difficult to document as records were usually not available. The findings on uncles and aunts are shown in table 5. Among the 1191 uncles and aunts of index patients with spina bifida, seven had spina bifida (5.9 per 1000), and among the 832 uncles and aunts of index patients with anencephalus, four had spina bifida (4.8 per 1000). The lack of anencephalus cases among uncles and aunts was probably the result of parents of an anencephalic child usually being told that the child was stillborn.

\section{CONSANG UINITY OF PARENTS}

Only two index patients were born to consanguineous parents $(206,356)$. In one the parents were first cousins, and in the other second cousins. Of the 13 sibs in the latter family, none had a CNS malformation. In the other family, the only other pregnancy ended as a spontaneous abortion.

NON-CNS MALFORMATIONS AMONG SIBS

The sibs with malformations other than those of the central nervous system are shown in appendix 2 . Among 710 sibs, 15 had a major congenital malformation. These included three patients with congenital dislocation of the hip, two with pyloric stenosis, one with microcephaly, one with Down's syndrome, one with talipes equinovarus, one with cleft palate, one with congenital heart defect, one with imperforate anus, bilateral talipes equinovarus, imperforate urethra, and absent scrotum and penis, one with oesophageal atresia, one with oesophageal atresia and congenital heart defect, one with oesophageal atresia, tracheo-oesophageal fistula, common atrium, coarctation of the aorta, dilatation of the bladder, and bilateral hydronephrosis, and one with hare lip, cleft palate, and congenital heart disease.

\section{Discussion}

The present study was undertaken to assess the risk of spina bifida and anencephalus among sibs of index patients with these malformations. The proportion of affected sibs is in good agreement with that found in other United Kingdom studies. Table 6 compares the proportion of affected sibs in major surveys in the United Kingdom over the past 15 years. The proportion of affected sibs in the present survey is $8.87 \%$. This estimate is higher than the 4 to $5 \%$ commonly reported, and may be because of the background of the Ulster population which is known to have the highest incidence of these 
TABLE 6 UK studies in population incidence and proportion of sibs affected

\begin{tabular}{|c|c|c|c|c|c|c|}
\hline \multirow[b]{2}{*}{ Southampton 6} & \multirow{2}{*}{$\begin{array}{l}\text { Index patient } \\
\text { Spina bifida } \\
\text { Anencephalus }\end{array}$} & \multirow{2}{*}{$\begin{array}{l}\begin{array}{l}\text { Population incidence } \\
(\%)\end{array} \\
\left.\begin{array}{l}0.32 \\
0.19\end{array}\right\} 0.51\end{array}$} & \multicolumn{2}{|c|}{$\begin{array}{l}\text { Sibs with } \\
\text { CNS malformation }\end{array}$} & \multirow{2}{*}{$\frac{\%}{5 \cdot 63}$} & $\begin{array}{l}\text { Relative to } \\
\text { population }\end{array}$ \\
\hline & & & $\begin{array}{l}7 / 119 \\
2 / 41\end{array}$ & $\begin{array}{l}5 \cdot 89 \\
4 \cdot 89\end{array}$ & & $\times 11 \cdot 0$ \\
\hline South Wales 3 & $\begin{array}{l}\text { Spina bifida } \\
\text { Anencephalus }\end{array}$ & $\begin{array}{l}0.41 \\
0.35\end{array}$ & $\begin{array}{l}52 / 854 \\
29 / 709\end{array}$ & $\begin{array}{l}6 \cdot 09 \\
4 \cdot 10\end{array}$ & $5 \cdot 18$ & $\times \quad 6.8$ \\
\hline Greater London7 & $\begin{array}{l}\text { Spina bifida } \\
\text { Anencephalus }\end{array}$ & $\left.\begin{array}{l}0.15 \\
0.14\end{array}\right\} 0.29$ & $\begin{array}{l}25 / 730 \\
41 / 754\end{array}$ & $\begin{array}{l}3 \cdot 42 \\
5 \cdot 44\end{array}$ & 4.45 & $\times 15 \cdot 3$ \\
\hline Glasgow5 & $\begin{array}{l}\text { Spina bifida } \\
\text { Anencephalus }\end{array}$ & $\left.\begin{array}{l}0.28 \\
0.28\end{array}\right\} 0.56$ & $\begin{array}{l}25 / 450 \\
26 / 454\end{array}$ & $\begin{array}{l}5 \cdot 56 \\
5 \cdot 73\end{array}$ & $5 \cdot 64$ & $\times 10 \cdot 1$ \\
\hline Belfast & $\begin{array}{l}\text { Spina bifida } \\
\text { Anencephalus }\end{array}$ & $\left.\begin{array}{l}0.45 \\
0.42\end{array}\right\} 0.87$ & $\begin{array}{l}45 / 432 \\
18 / 278\end{array}$ & $\begin{array}{r}10.42 \\
6.47\end{array}$ & $8 \cdot 87$ & $\times 10 \cdot 2$ \\
\hline
\end{tabular}

malformations in the world. In Belfast (1964 to 1968) the incidence was 8.7 per 1000 total births, ${ }^{1}$ and more recently 7.6 per 1000 total births. ${ }^{4}$ However, when the percentage of affected sibs relative to the population incidence is examined, the findings in Belfast are similar to those of Glasgow ${ }^{5}$ and of Southampton. ${ }^{6}$ The proportion of affected sibs, which is ten times the population incidence, is greater in London, ${ }^{7}$ and less in South Wales. ${ }^{3}$ The size of this risk among sibs of affected subjects indicates the importance of genetic counselling and prenatal diagnosis in monitoring pregnancies of women who have had an infant with a CNS malformation.

There was a higher proportion of affected sibs of spina bifida than of anencephalic index patients. A similar finding was noted in the South Wales ${ }^{3}$ and in the Southampton ${ }^{6}$ surveys, whereas the reverse was observed in the London ${ }^{7}$ and Glasgow ${ }^{5}$ studies. $\vec{v}$ However, the differences were not significant. The $\omega$ recurrence risks among sibs before and after the $\underset{\omega}{\triangle}$ index patient were similar, $8.3 \%$ and $9.7 \%$, respectively. This is in agreement with other family studies (table 7).

The recurrence rate after two affected children is higher than after one. ${ }^{8}$ Since a certain proportion ${ }^{\Phi}$ of spontaneous abortions are the result of a CNS $\vec{\oplus}$

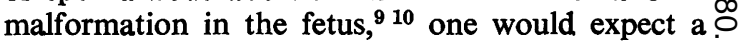
higher recurrence rate if a preceding pregnancy had resulted in a spontaneous abortion. The recurrence rate was calculated according to whether the mother had had a spontaneous abortion before the index patient (table 8). In sibships with at least one $\frac{\square}{\square}$ spontaneous abortion before the index patient, the proportion of affected sibs was 1 in $11 \cdot 2$, whereas, $\frac{0}{3}$ if the index patient was the first pregnancy, or if

TABLE 7 Recurrence risks among sibs before and after the index patients

\begin{tabular}{|c|c|c|c|}
\hline & Previous sibs & Subsequent sibs & \\
\hline $\begin{array}{l}\text { Williamson } 6 \\
\text { Carter } \text { et }^{6} \text { al }^{3} \\
\text { Carter and Evans } 7 \\
\text { Janerich and Piper } 11 \\
\text { Present paper }\end{array}$ & $\begin{array}{r}6 / 106(5 \cdot 7 \%) \\
45 / 1023(4.4 \%) \\
38 / 877(4.3 \%) \\
9 / 295(3.1 \%) \\
35 / 420(8.3 \%)\end{array}$ & $\begin{array}{cc}3 / 55 & (5.5 \%) \\
26 / 539 & (4.8 \%) \\
28 / 607 & (4.6 \%) \\
10 / 742 & (1.4 \%) \\
28 / 290 & (9.7 \%)\end{array}$ & $\begin{array}{l}\chi^{2}=0.0947 ; 0.8>p>0.7 \\
\chi^{2}=0.0652 ; 0.8>p>0.7 \\
\chi^{2}=0.0166 ; 0.9>p>0.8 \\
\chi^{2}=2.523 ; 0.2>p>0.1 \\
\chi^{2}=0.2252 ; 0.7>p>0.5\end{array}$ \\
\hline
\end{tabular}

TABLE 8 Recurrence risks among offspring of mothers with an infant with a CNS malformation depending on outcome of pregnancies before the index patient

\begin{tabular}{|c|c|c|c|c|}
\hline \multirow[t]{2}{*}{ Study } & \multirow{2}{*}{$\begin{array}{l}\text { Lesion in } \\
\text { index patient }\end{array}$} & \multicolumn{3}{|c|}{ Outcome of pregnancies before index patient } \\
\hline & & None & Normal livebirths & $\begin{array}{l}\text { Presence of } \\
\text { at least one } \\
\text { spontaneous abortion }\end{array}$ \\
\hline Belfast & $\begin{array}{l}\text { Spina bifida } \\
\text { Anencephalus }\end{array}$ & $\begin{array}{l}4 \text { in } 46 \quad(1 \text { in } 11 \cdot 5) \\
3 \text { in } 51 \quad(1 \text { in } 17 \cdot 0)\end{array}$ & $\begin{array}{ll}6 \text { in } 63 & (1 \text { in } 10 \cdot 5) \\
5 \text { in } 41 & (1 \text { in } 8 \cdot 2)\end{array}$ & $\begin{array}{l}5 \text { in } 26(1 \text { in } 5 \cdot 2) \\
0 \text { in } 31(-1-)\end{array}$ \\
\hline \multirow[t]{2}{*}{ South Wales ${ }^{3}$} & $\begin{array}{l}\text { Total } \\
\text { Spina bifida } \\
\text { Anencephalus }\end{array}$ & $\begin{array}{l}7 \text { in } 97(1 \text { in } 13 \cdot 9) \\
8 \text { in } 156(1 \text { in } 19 \cdot 5) \\
3 \text { in } 117(1 \text { in } 39 \cdot 0)\end{array}$ & $\begin{array}{l}11 \text { in } 104(1 \text { in } 9 \cdot 5) \\
4 \text { in } 96(1 \text { in } 24 \cdot 0) \\
4 \text { in } 77(1 \text { in } 19 \cdot 3)\end{array}$ & $\begin{array}{l}5 \text { in } 57(1 \text { in } 11 \cdot 2) \\
1 \text { in } 46(1 \text { in } 46 \cdot 0) \\
4 \text { in } 35(1 \text { in } 8 \cdot 8)\end{array}$ \\
\hline & Total & 11 in $273(1$ in $24 \cdot 8)$ & $\overline{8 \text { in } 173(1 \text { in } 21 \cdot 6)}$ & $\overline{5 \text { in } 81(1 \text { in } 16 \cdot 2)}$ \\
\hline
\end{tabular}


only live births preceded the index patient, the proportion of affected sibs was 1 in 13.9 and 1 in 9.5 , respectively. The difference in these three proportions was not significant $\left(\chi^{2}=0 \cdot 74 ; 0.98>\right.$ $\mathrm{p}>0.95$ ) and suggests that a history of a previous miscarriage is not an important factor in determining recurrence risk. The South Wales study ${ }^{3}$ was analysed in a similar manner. The proportion of affected sibs in the three groups was 1 in $16 \cdot 2,1$ in $24 \cdot 8$, and 1 in $21 \cdot 6$. Again, the difference in these three rates was not significant $(\mathrm{p}=0.63)$.

There is a tendency for an affected sib to have the same type of CNS malformation as the index patient (table 9). Of 46 families with two sibs with CNS malformations, 28 had similar and 18 dissimilar lesions.
TABLE 9 Tendency for affected sibs to have the same CNS malformation as index patient

\begin{tabular}{llll}
\hline $\begin{array}{l}\text { Index } \\
\text { patient }\end{array}$ & \multicolumn{2}{l}{ Sib } & Same : Different \\
\cline { 2 - 3 } & Spinabifida & Anencephalus & \\
\hline Spina bifida & 22 & 10 & $28: 18$ \\
Anencephalus & 8 & 6 & \\
\hline
\end{tabular}

This work was aided by grants from the Belfast, Lurgan, and Mid-Ulster Branches of the Association for Spina Bifida and Hydrocephalus. We are grateful to Mr David Bradley, Department of Medical Statistics, The Queen's University of Belfast for the statistical analyses.

APPENDIX 1 Index patients and sibs

$M$, male; F, female; m, miscarriage; sb, stillbirth; * index patient ; [ ], twins; $(A)$, anencephalus; $(S)$, spina bifida; $(H)$, hydrocephalus.

\begin{tabular}{lll}
\hline Serial No Sibship & Date of birth \\
\hline & $\frac{\text { Mother }}{\text { Father }}$ \\
\hline
\end{tabular}

\section{A. SPINA BIFIDA}

\begin{tabular}{|c|c|c|c|}
\hline \multicolumn{4}{|c|}{ One child families } \\
\hline 059 & *F(S)7/64 & 1928 & 1926 \\
\hline 067 & $* F(S) 8 / 64$ & 1929 & 1927 \\
\hline 206 & ${ }^{*} \mathrm{~F}(\mathrm{~S}) 3 / 66 \mathrm{sb} ; \mathrm{m}-/ 67$ & 1937 & 1920 \\
\hline 207 & ${ }^{*} \mathrm{~F}(\mathrm{~S}) 7 / 66$ & 1941 & 1936 \\
\hline 347 & ${ }^{*} \mathrm{M}(\mathrm{S}) 1 / 68$ & 1947 & 1944 \\
\hline \multicolumn{4}{|c|}{ Two child families } \\
\hline 009 & *F(S)1/64;M3/65 & 1942 & 1938 \\
\hline 049 & $\mathrm{~m} 6 / 59 ; \mathrm{m12} / 59 ; \mathrm{F} 5 / 61 \mathrm{sb} ; \mathrm{m} 12 / 61 ; \mathrm{m} 3 / 62 ; \mathrm{m12} / 62 ; \mathrm{m} 4 / 63 ; * \mathrm{~F}(\mathrm{~S}) 6 / 64$ & 1932 & 1929 \\
\hline 105 & ${ }^{*} \mathrm{M}(\mathrm{S}) 2 / 65 ; \mathrm{M} 1 / 68$ & 1939 & 1940 \\
\hline 117 & ${ }^{*} \mathrm{~F}(\mathrm{~S}) 4 / 65 ; \mathrm{F} 3 / 67$ & 1946 & 1937 \\
\hline 128 & F5/60;*M(S)8/65 & 1928 & 1926 \\
\hline 148 & $\mathrm{~m}-/ 62 ; \mathrm{F} 8 / 63 ; * \mathrm{M}(\mathrm{S}) 8 / 65 \mathrm{sb}$ & 1931 & 1934 \\
\hline 160 & ${ }^{*} \mathrm{~F}(\mathrm{~S}) 10 / 65 ; \mathrm{M} 1 / 70$ & 1945 & 1943 \\
\hline 165 & $* \mathrm{M}(\mathrm{S}) 10 / 65 ; \mathrm{M} 2 / 67$ & 1947 & 1946 \\
\hline 167 & ${ }^{*} \mathrm{~F}(\mathrm{~S}) 11 / 65 ; \mathrm{m} 5 / 67 ; \mathrm{m9} / 67 ; \mathrm{m} 1 / 70 ; \mathrm{M} 4 / 71$ & 1944 & 1944 \\
\hline 200 & $\mathrm{M} 3 / 61 ; \mathbf{M}(\mathbf{S}) 2 / 66 \mathrm{sb}$ & 1935 & 1927 \\
\hline 231 & *F(S)7/66sb;M5/70 & 1947 & 1945 \\
\hline 235 & $* \mathrm{M}(\mathrm{S}) 7 / 66 ; \mathrm{F} 11 / 71$ & 1942 & 1941 \\
\hline 262 & $\mathrm{M} 2 / 63 ;{ }^{*} \mathrm{M}(\mathrm{S}) 12 / 66$ & 1932 & 1930 \\
\hline 264 & ${ }^{*} \mathrm{~F}(\mathrm{~S}) 7 / 66 ; \mathrm{M} 9 / 70$ & 1941 & 1940 \\
\hline 269 & M7/62;*F(S)2/67sb & 1942 & 1938 \\
\hline 288 & $\mathrm{M} 10 / 65 ; \mathbf{M}(\mathrm{S}) 4 / 67$ & 1941 & 1936 \\
\hline 307 & $\mathrm{M} 9 / 62 ; * \mathrm{~F}(\mathrm{~S}) 7 / 67$ & 1939 & 1938 \\
\hline 319 & *M(S) $9 / 67 ; \mathrm{F} 8 / 72$ & 1949 & 1947 \\
\hline 351 & ${ }^{*} \mathrm{~F}(\mathrm{~S}) 3 / 68 ; \mathrm{F} 10 / 70$ & 1945 & 1947 \\
\hline 366 & ${ }^{*} \mathrm{~F}(\mathrm{~S}) 11 / 68 ; \mathrm{M} 7 / 72$ & 1948 & 1939 \\
\hline 374 & F $1 / 57 ; * M(S) 2 / 68$ & 1931 & 1929 \\
\hline 382 & $\mathrm{~F} 8 / 60 ; \mathrm{F}(\mathrm{S}) 5 / 68$ & 1934 & 1930 \\
\hline 521 & ${ }^{*} \mathrm{~F}(\mathrm{~S}) 7 / 68 ; \mathrm{M} 6 / 74$ & 1945 & 1947 \\
\hline \multicolumn{4}{|c|}{ Three child families } \\
\hline 007 & F5/56;F5/60;*F(S) $1 / 64$ & 1925 & 1925 \\
\hline 010 & $\mathrm{M} 1 / 57 ; \mathrm{m} 7 / 60 ; * \mathrm{~F}(\mathrm{~S}) 1 / 64 ; \mathrm{M} 5 / 66 ; \mathrm{m} 9 / 68$ & 1935 & 1934 \\
\hline 023 & $\mathrm{~F} 2 / 63 ;{ }^{*} \mathrm{~F}(\mathrm{~S}) 3 / 64 ; \mathrm{F} 2 / 70$ & 1940 & 1942 \\
\hline 038 & $\mathrm{M} 9 / 49 ; \mathrm{m} 6 / 53 ; \mathrm{F} 4 / 58 ; * \mathrm{M}(\mathrm{S}) 5 / 64$ & 1927 & 1920 \\
\hline 043 & $\mathrm{M} 7 / 50 ; \mathrm{m} 6 / 51 ; \mathrm{m8} / 52 ; \mathrm{M} 4 / 55 ; \mathrm{m} 8 / 60 ; \mathrm{m} 4 / 63 ; * \mathrm{M}(\mathrm{S}) 6 / 64$ & 1926 & 1925 \\
\hline 050 & $\mathrm{M} 3 / 58 ; \mathrm{M} 4 / 60 ; * \mathrm{~F}(\mathrm{~S}) 7 / 64$ & 1928 & 1926 \\
\hline 062 & $\mathrm{M} 8 / 61 ; \mathrm{m} 4 / 62 ; \mathrm{m} 2 / 63 ; * \mathrm{~F}(\mathrm{~S}) 8 / 64 ; \mathrm{M} 5 / 67$ & 1939 & 1934 \\
\hline 119 & F4/60;*M(S)5/65;m-/66;m-/67;M12/68;m12/72 & 1934 & 1938 \\
\hline
\end{tabular}


APPENDIX 1 -continued

Serial No Sibship Date of birth

Three child families-continued

\begin{tabular}{|c|c|c|c|}
\hline $\begin{array}{l}125 \\
199 \\
209 \\
216 \\
217 \\
233 \\
243 \\
244 \\
252 \\
256 \\
310 \\
344 \\
345 \\
358\end{array}$ & 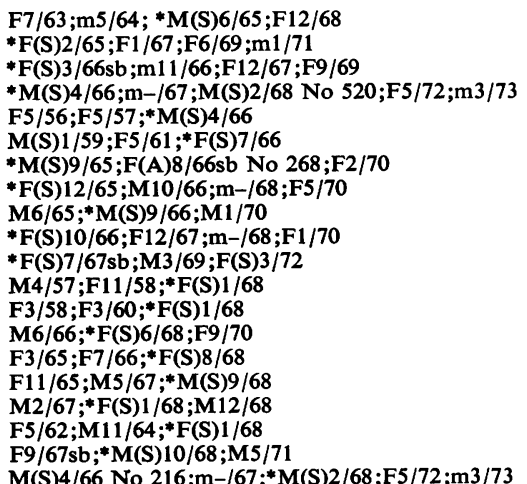 & $\begin{array}{l}1942 \\
1932 \\
1936 \\
1940 \\
1926 \\
1936 \\
1944 \\
1942 \\
1944 \\
1946 \\
1942 \\
1926 \\
1937 \\
1947 \\
1946 \\
1943 \\
1946 \\
1940 \\
1945 \\
1940\end{array}$ & $\begin{array}{l}1943 \\
1933 \\
1937 \\
1942 \\
1931 \\
1929 \\
1946 \\
1942 \\
1942 \\
1944 \\
1943 \\
1921 \\
1933 \\
1944 \\
1945 \\
1934 \\
1943 \\
1936 \\
1945 \\
1942\end{array}$ \\
\hline
\end{tabular}

Four child families

$005 \quad M 11 / 54 ; F 7 / 56 ; \mathrm{F}(\mathrm{S}) 9 / 61 ;{ }^{*} \mathrm{~F}(\mathrm{~S}) 1 / 64 ; \mathrm{m5} / 67$

$016 \quad$ F(A)9/61sb;M8/62;*M(S)2/64sb;m7/65;M(A)4/67 No 286

F12/58;M4/60;M2/62;*M(S)3/64

m1 $/ 62 ; M(A) 10 / 62 \mathrm{sb} ; * \mathrm{M}(\mathrm{S}) 10 / 64 ; \mathrm{F}(\mathrm{S}) 10 / 66$ No $245 ; \mathrm{m} 8 / 68 ; \mathrm{F} 2 / 70$

*M(S) $8 / 64 ; \mathrm{m1} 12 / 64 ; \mathrm{M} 1 / 66 ; \mathrm{F5} / 69 ; \mathrm{F5} / 72$

$\mathrm{m} 2 / 56 ; \mathrm{m6} / 56 ; \mathrm{m} 9 / 57 ; \mathrm{M} 3 / 59 ; \mathrm{m} 4 / 60 ; \mathrm{m1} / 61 ; \mathrm{M} 2 / 62 ; \mathrm{m}-163 ; \mathrm{m}-163 ; \mathrm{m} 2 / 64 ; * \mathrm{~F}(\mathrm{~S}) 11 / 64 ; \mathrm{M} 7 / 66$

*M(S) $11 / 64 ;$ m4/65;F6/66,M6/67;M3/70

M4/62;m6/63;*M(S) $1 / 64 ; F 8 / 66 ; F 7 / 67$

$\mathrm{M} 9 / 61 ; \mathrm{F} 9 / 62 ; \mathrm{F} 10 / 63 ;{ }^{*} \mathrm{~F}(\mathrm{~S}) 9 / 64$

F7/61;M7/62;*M(S)7/65;M8/69

$\mathrm{M} 10 / 53 ; \mathrm{F} 4 / 57 ; \mathrm{F} 7 / 58 ; * \mathrm{M}(\mathrm{S}) 10 / 65 \mathrm{sb}$

M9/60;F3/62;*F(S) $5 / 65 ; \mathrm{m} 2 / 69 ; \mathrm{M} 12 / 69$

*F(S)2/66;M6/67;F8/68;M8/70

M12/54;F5/62;M6/64;*M(S) $1 / 66$

M3/61;M5/62;M8/63;*F(S) 8/66

$\mathrm{m1} / 62 ; \mathrm{M}(\mathrm{A}) 10 / 62 \mathrm{sb} ; \mathrm{M}(\mathrm{S}) 10 / 64$ No $024 ;{ }^{*} \mathrm{~F}(\mathrm{~S}) 10 / 66 ; \mathrm{m} 12 / 67 ; \mathrm{m} 8 / 68 ; \mathrm{F} 2 / 70$

*F(S) $7 / 67 ; F 3 / 69 ; F 3 / 71 ; F 8 / 72$

F2 $/ 64 ; F 6 / 65 ; *$ M(S) $7 / 67 ; M 2 / 72$

M7/63;m-/66;*M(S)8/67sb;M4/69;M2/72

M2/64;F12/65;*M(S)12/67;M11/70

F8/66;*M(S)6/68;M8/70;F11/71

*F(S)7/67;M12/68;M(A)4/71 sb;M10/72

M6/64;*M(S) $4 / 67 ; M 12 / 68 ; F(A) 4 / 70$ sb

F4/65;*F(S)6/68sb;F9/69;F11/71

Five child families

\begin{tabular}{|c|c|}
\hline $\begin{array}{l}013 \\
014 \\
111 \\
112 \\
115 \\
116 \\
135 \\
138 \\
140 \\
188 \\
189 \\
191 \\
208 \\
214 \\
236 \\
266 \\
315 \\
384\end{array}$ & $\begin{array}{l}\text { m2/63;*M(S)2/64;M2/65;M6/66;M5/67;M(S)6/69;m1/70 } \\
\text { M9/63;*M(S)4/64;F(S)12/65sb No } 115 ; \mathrm{m}-/ 67 ; \mathrm{m}-/ 69 ; \mathrm{M} 5 / 70 ; \mathrm{M} 3 / 72 \\
\text { M12/46;M10/49;M6/58;*M(S)3/65sb;F2/67 } \\
\text { M1/61;F2/62;M4/63;*M(S)3/65;F6/66 } \\
\text { M9/63;M(S)4/64 No 014;*F(S)12/65sb;m-/67;m-/69;M5/70;M3/72 } \\
\text { F11/48;M3/51;*M(S)5/65sb;M7/67;M11/69 } \\
\text { M6/55;M4/57;F1/69;F8/60;*F(S)7/65 } \\
\text { F1/61;M10/62;*F(S)10/65;F10/67;F6/71 } \\
\text { F1/62;M(S)8/63;M7/64;*F(S)11/65;F4/69 } \\
\text { M(S)11/63;m12/63;M1/65;*F(S)3/66;M2/67;F1/70 } \\
\text { *F(S)1/66;F11/66;M10/67;F10/68;M12/71 } \\
\text { M2/63;F(A)11/64 No 95;M(S)1/66;F7/68;F1/70 } \\
\text { M12/44;[F5/57;M5/57];M6/60:*M(S)3/66 } \\
\text { m2/62;M(A)10/63sb;M11/64;*M(S)4/66;F7/68;F(S)11/72 } \\
\text { F4/58;F3/59;M10/61;M12/63;m-/64;m-/65;*F(S)6/66 } \\
\text { M11/54;M7/57;F4/49;F5/61;*F(S)1/67 } \\
\text { M10/64;F8/66;*F(S)8/67;M8/68;m4/70;F5/71 } \\
\text { F(S)1/61;M3/62;M2/65;*F(S)5/67;F2/69 }\end{array}$ \\
\hline
\end{tabular}


APPENDIX 1-continued

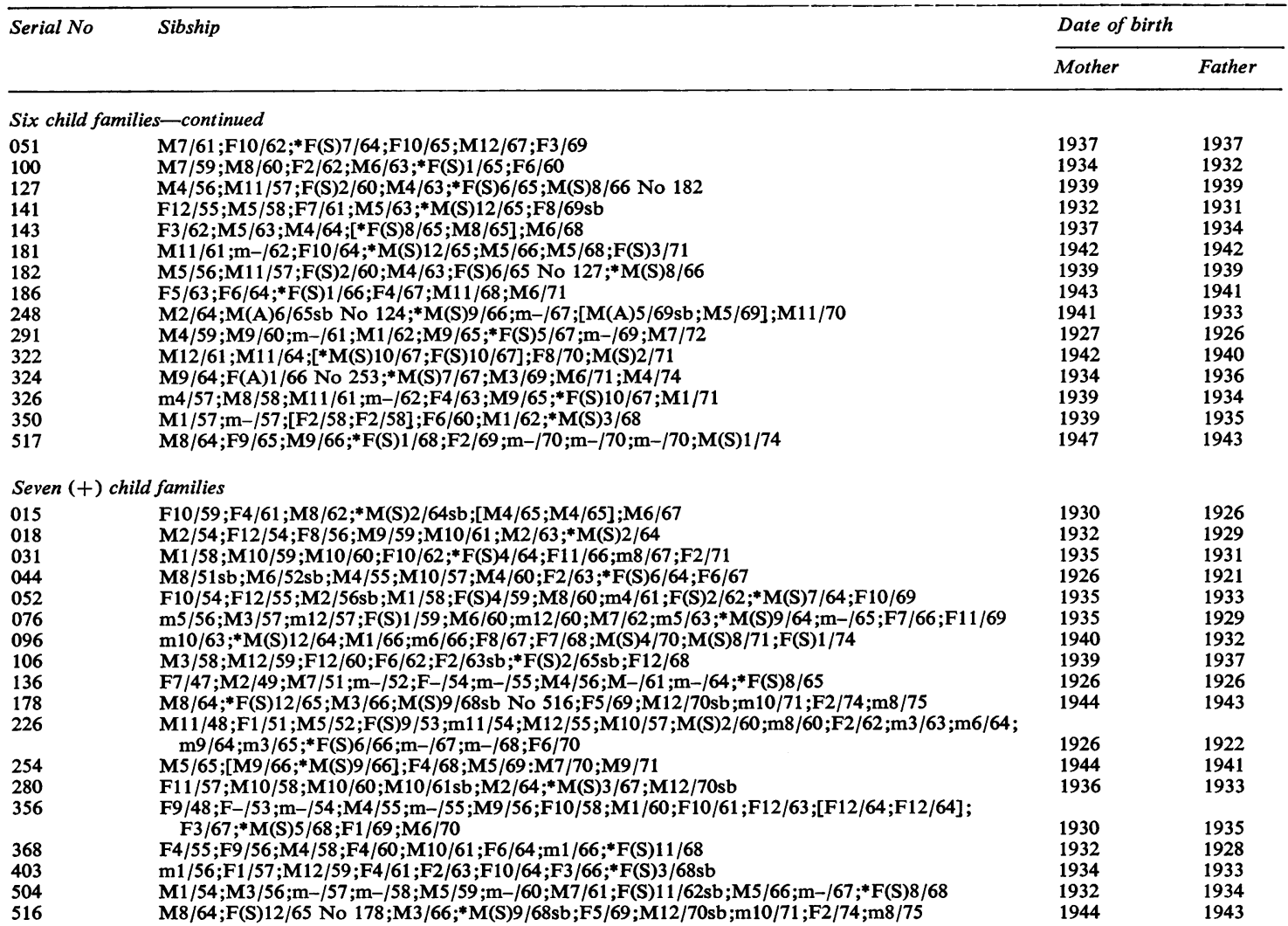

\section{B. ANENCEPHALUS}

One child families

$\begin{array}{ll}227 & \mathrm{~m}-/ 60 ; * \mathrm{M}(\mathrm{A}) 6 / 66 \mathrm{sb} \\ 397 & \mathrm{~m}-/ 65 ; * \mathrm{~F}(\mathrm{~A}) 2 / 68 \mathrm{sb}\end{array}$

Two child families

$\begin{array}{ll}037 & \text { F9/44;m6/49;*F(A)5/64sb;m-/64 } \\ 040 & \text { *F(A)8/64sb;m10/66;M6/70 } \\ 123 & \text { M4/63;*M(A)5/65sb } \\ 139 & \text { M8/63;m5/64;*F(A)8/65sb;m-/67 } \\ 168 & \text { *F(A)2/65sb;F(A)11/66sb No } 221 \\ 180 & \text { *F(A)12/65sb;m9/66;F3/68 } \\ 219 & \text { *F(A)5/66sb;F4/68 } \\ 220 & \text { F9/64;*F(A)5/66sb } \\ 221 & \text { F(A)2/65sb No } 168 ; * F(A) 11 / 66 s b \\ 285 & \text { m-/64;F(H)2/65;*F(A)7/66sb } \\ 289 & \text { F9/62;*F(A)3/67sb } \\ 306 & \text { *M(A)7/67;F(S)6/70sb } \\ 338 & \text { F8/62;m8/64;*F(A)11/67 } \\ 378 & \text { m2/56;m-/57;F12/63;m-/64;*F(A)3/68 } \\ 385 & \text { *F(A)6/68;F9/69 } \\ 511 & \text { m1/68;*F(A)10/68sb;M12/71 } \\ 522 & \text { M(A)7/59sb;m4/60;*F(A)12/68sb }\end{array}$

$\begin{array}{ll}1923 & 1919 \\ 1935 & 1936 \\ 1935 & 1930 \\ 1925 & 1928 \\ 1940 & 1932 \\ 1941 & 1941 \\ 1945 & 1942 \\ 1947 & 1947 \\ 1940 & 1932 \\ 1942 & 1940 \\ 1926 & 1927 \\ 1939 & 1945 \\ 1937 & 1937 \\ 1935 & 1929 \\ 1944 & 1942 \\ 1942 & 1939 \\ 1939 & 1935 \\ & \\ & \\ 1932 & 1928 \\ 1944 & 1943 \\ 1939 & 1932 \\ 1934 & 1934\end{array}$

Three child families

$\begin{array}{ll}137 & \text { M8/60;M6/62;*F(A)2/65sb } \\ 154 & \text { *F(A)9/65sb;F5/67;M } 1 / 70 \\ 157 & \text { F(A)10/58sb;M3/62;*M(A)8/65sb;m-70 } \\ 159 & \text { M6/62;m-/63;M12/64;*M(A)7/66sb }\end{array}$


APPENDIX 1-continued

\begin{tabular}{|c|c|c|c|}
\hline \multirow[t]{2}{*}{ Serial No } & \multirow[t]{2}{*}{ Sibship } & \multicolumn{2}{|c|}{ Date of birth } \\
\hline & & Mother & Father \\
\hline 183 & $\mathrm{~F}(\mathrm{~S}) 6 / 61 ;{ }^{*} \mathrm{~F}(\mathrm{~A}) 1 / 66 \mathrm{sb} ; \mathrm{M} 2 / 70$ & 1936 & 1935 \\
\hline 193 & $\mathrm{~m}-/ 65 ; * \mathrm{M}(\mathrm{A}) 1 / 66 \mathrm{sb} ;[\mathrm{M} 7 / 67 ; \mathrm{M} 7 / 67]$ & 1943 & 1943 \\
\hline 195 & $\mathrm{~F} 10 / 64 ; * \mathrm{~F}(\mathrm{~A}) 1 / 66 \mathrm{sb} ; \mathrm{F} 8 / 70$ & 1937 & 1935 \\
\hline 197 & ${ }^{*} \mathrm{~F}(\mathrm{~A}) 2 / 66 ; \mathrm{M} 8 / 67 ; \mathrm{M} 8 / 71$ & 1947 & 1946 \\
\hline 211 & $\mathrm{M} 6 / 62 ; \mathrm{m}-/ 63 ; \mathrm{M} 12 / 64 ; * \mathrm{M}(\mathrm{A}) 7 / 66 \mathrm{sb}$ & 1934 & 1934 \\
\hline 256 & ${ }^{*} \mathrm{~F}(\mathrm{~A}) 10 / 66 \mathrm{sb} ; \mathrm{F} 12 / 67 ; \mathrm{m}-/ 68 ; \mathrm{F} 1 / 70$ & 1946 & 1944 \\
\hline 257 & ${ }^{*} \mathrm{M}(\mathrm{A}) 11 / 66 ; \mathrm{F} 11 / 67 ; \mathrm{M} 6 / 69$ & 1946 & 1946 \\
\hline 267 & $\mathrm{~m}-/ 59 ; \mathrm{F} 1 / 61 \mathrm{sb} ; \mathrm{m} 1 / 63 ; \mathrm{M} 1 / 64 ; \mathrm{m}-/ 66 ; * \mathrm{~F}(\mathrm{~A}) 6 / 67 \mathrm{sb}$ & 1933 & 1931 \\
\hline 268 & $M(S) 9 / 65$ No $243 ; * F(A) 8 / 66 s b ; F 2 / 70$ & 1946 & 1944 \\
\hline 271 & *F(A) $1 / 67 \mathrm{sb} ; \mathrm{M} 1 / 68 ; \mathrm{M} 4 / 71$ & 1947 & 1946 \\
\hline 272 & F1 $/ 65 ; * M(A) 1 / 67 s b ; F 3 / 69$ & 1932 & 1931 \\
\hline 334 & $\mathrm{~F} 12 / 66 ; * \mathrm{~F}(\mathrm{~A}) 11 / 67 \mathrm{sb} ; \mathrm{m} 3 / 68 ; \mathrm{F} 3 / 69 ; \mathrm{ml} / 71 ; \mathrm{m} 7 / 71$ & 1943 & 1942 \\
\hline 335 & ${ }^{*} \mathrm{M}(\mathrm{A}) 11 / 67 \mathrm{sb} ; \mathrm{F} 3 / 69 ; \mathrm{M} 5 / 70$ & 1945 & 1945 \\
\hline 399 & M4/62;*M(A) $3 / 68 \mathrm{sb} ; \mathrm{M} 12 / 71$ & 1936 & 1935 \\
\hline 401 & ${ }^{*} \mathrm{M}(\mathrm{A}) 3 / 68 \mathrm{sb} ; \mathrm{F} 4 / 69 ; \mathrm{M} 5 / 72$ & 1945 & 1942 \\
\hline 500 & ${ }^{*} \mathrm{~F}(\mathrm{~A}) 7 / 68 \mathrm{sb} ; \mathrm{M} 1 / 70 ; \mathrm{M} 8 / 71$ & 1941 & 1942 \\
\hline 501 & $\mathrm{~m}-/ 67 ; * \mathrm{M}(\mathrm{A}) 8 / 68 \mathrm{sb} ; \mathrm{F} 8 / 69 ; \mathrm{F} 3 / 71$ & 1948 & 1946 \\
\hline 510 & ${ }^{*} \mathrm{~F}(\mathrm{~A}) 10 / 68 \mathrm{sb} ; \mathrm{m}-/ 68 ; \mathrm{M} 3 / 71 ; \mathrm{M} 2 / 72$ & 1950 & 1949 \\
\hline 514 & M12/66;*F(A)12/68sb;m12/69;F3/71 & 1940 & 1936 \\
\hline
\end{tabular}

Four child families

\begin{tabular}{|c|c|}
\hline 071 & M7/56;M9/57;F7/60;*F(A)9/64sb \\
\hline 074 & ${ }^{*} \mathrm{~F}(\mathrm{~A}) 9 / 64 \mathrm{sb} ; \mathrm{F} 5 / 67 ; \mathrm{M} 9 / 68 ; \mathrm{M} 6 / 70$ \\
\hline 078 & $\mathrm{m6} / 63 ;{ }^{*} \mathrm{M}(\mathrm{A}) 9 / 64 ; \mathrm{M} 12 / 65 ;[\mathrm{F} 10 / 66 ; \mathrm{F} 10 / 66]$ \\
\hline 079 & F7/63;*M(A)9/64sb;M9/65;M(S)5/69 \\
\hline 130 & $\mathrm{M}(\mathrm{A}) 3 / 60 \mathrm{sb} ; \mathrm{M}(\mathrm{S}) 7 / 61 ; \mathrm{M} 7 / 63 ;{ }^{*} \mathrm{~F}(\mathrm{~A}) 7 / 65$ \\
\hline 131 & M3/47;M9/50;M12/59sb;*F(A)8/65sb \\
\hline 155 & F9/63sb;m4/64;*F(A)9/65sb;M5/68;M11/70 \\
\hline 156 & ${ }^{*} \mathrm{~F}(\mathrm{~A}) 10 / 65 \mathrm{sb} ; \mathrm{F} 9 / 66 ; \mathrm{m}-/ 67 ; \mathrm{M}(\mathrm{A}) 7 / 68 \mathrm{sb}$ No $408 ; \mathrm{M} 1 / 72$ \\
\hline 203 & F10/61;*F(A) $3 / 66 ; F 12 / 69 ; M 2 / 72$ \\
\hline 249 & F12/61;M4/64;*F(A)9/66;M12/67 \\
\hline 261 & F12/64;*M(A) $12 / 66 ; M 8 / 68 ; F 9 / 69$ \\
\hline 273 & ${ }^{*} \mathrm{~F}(\mathrm{~A}) 2 / 67 ; \mathrm{F5} / 68 ; \mathrm{M} 1 / 70 ; \mathrm{F} 5 / 71$ \\
\hline 286 & $\mathrm{~F}(\mathrm{~A}) 9 / 61 \mathrm{sb} ; \mathrm{M} 8 / 62 ; \mathrm{M}(\mathrm{S}) 2 / 64 \mathrm{sb}$ No $016 ; \mathrm{m} 7 / 65 ;{ }^{*} \mathrm{M}(\mathrm{A}) 4 / 67$ \\
\hline 292 & $\mathrm{~F} 1 / 60 ; \mathrm{M} 5 / 62 ; \mathrm{M} 6 / 64 ;{ }^{*} \mathrm{~F}(\mathrm{~A}) 6 / 67 \mathrm{sb}$ \\
\hline 300 & $\mathrm{~F} 8 / 65 ; * \mathrm{~F}(\mathrm{~A}) 6 / 67 \mathrm{sb} ; \mathrm{F} 4 / 69 ; \mathrm{M} 8 / 71$ \\
\hline 309 & F7/66;*F(A)7/67sb;F9/68;M10/71 \\
\hline 328 & $\mathrm{~F} 8 / 52 ; \mathrm{F} 8 / 53 ; \mathrm{m}-/ 54 ; \mathrm{M} 8 / 59 ; \mathrm{m}-/ 60 ; \mathrm{m}-/ 61 ; \mathrm{m} 9 / 65 ; * \mathrm{~F}(\mathrm{~A}) 9 / 67 \mathrm{sb}$ \\
\hline 329 & $\mathrm{M} 8 / 64 ; \mathrm{M} 10 / 65 ; * \mathrm{~F}(\mathrm{~A}) 9 / 67 ; \mathrm{m} 8 / 68 ; \mathrm{m} 8 / 69 ; \mathrm{F} 11 / 70$ \\
\hline 406 & F4/58;M3/61;M5/64;*M(A)6/68sb \\
\hline 408 & $\mathrm{~F}(\mathrm{~A}) 10 / 65 \mathrm{sb}$ No $156 ; \mathrm{F} 9 / 66 ; \mathrm{m}-/ 67 ;{ }^{*} \mathrm{M}(\mathrm{A}) 7 / 68 \mathrm{sb} ; \mathrm{M} 1 / 77$ \\
\hline
\end{tabular}


APPENDIX 1-continued

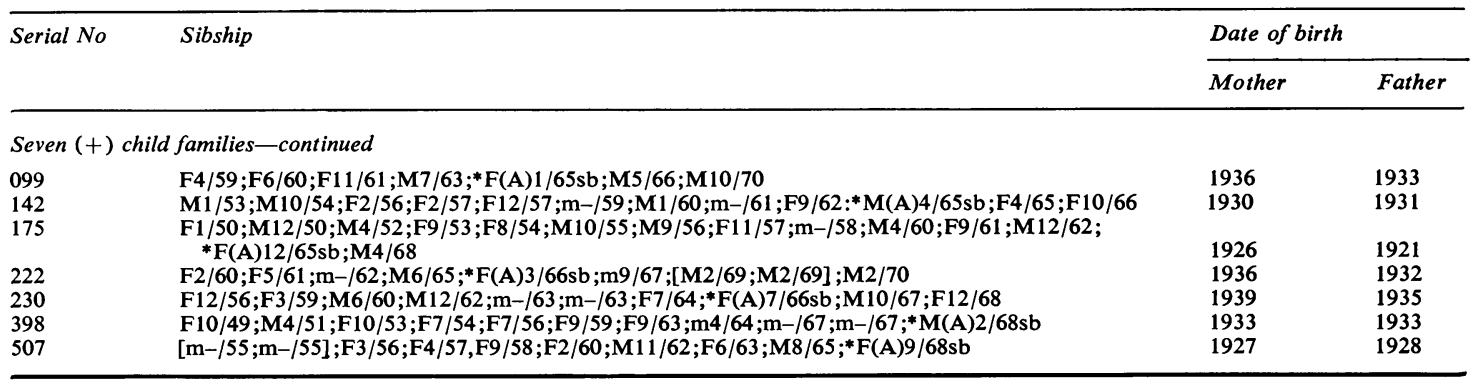

APPENDIX 2 Malformations (other than CNS malformation) in sibs of index patients

\begin{tabular}{|c|c|c|}
\hline Serial No & Sibship & Malformation \\
\hline \multicolumn{3}{|c|}{ Spina bifida index patient } \\
\hline 076 & F11/69 & Congenital dislocation of hip \\
\hline 087 & M3/70 & Bilateral congenital dislocation of hip \\
\hline 133 & F7/61 & Microcephaly \\
\hline 209 & F9/69 & Mental retardation \\
\hline 252 & M6/65 & Imperforate anus, bilateral talipes equinovarus, imperforate urethra, absent scrotum and penis \\
\hline 350 & M1/57 & Mental retardation \\
\hline 358 & M6/66 & Pyloric stenosis \\
\hline 368 & F9/56 & Cleft palate \\
\hline 382 & $\mathrm{~F} 8 / 60$ & Congenital heart defect \\
\hline 386 & $\mathrm{~F} 10 / 72$ & Down's syndrome \\
\hline 407 & F9/69 & Congenital dislocation of hip \\
\hline \multicolumn{3}{|c|}{ Anencephalus index patient } \\
\hline 075 & M1/62 & Talipes equinovarus \\
\hline 079 & M9/65 & $\begin{array}{l}\text { Oesophageal atresia, tracheo-oesophageal fistula, common atrium, coarctation of aorta, dilatation of bladder, } \\
\text { bilateral hydronephrosis }\end{array}$ \\
\hline 142 & F4/65 & Hare lip, cleft palate, and congenital heart defect \\
\hline 230 & F7/64 & Pyloric stenosis \\
\hline 328 & F8/52 & Mental retardation \\
\hline 406 & M3/61 & Oesophageal atresia \\
\hline 513 & F7/72 & Oesophageal atresia and absent right ventricle \\
\hline
\end{tabular}

\section{References}

1 Elwood JH, Nevin NC. Factors associated with anencephalus and spina bifida in Belfast. BrJ Prev Soc Med 1973;27:73-80.

2 Elwood JH, Nevin NC. Anencephalus and spina bifida in Belfast (1964-1968). Ulster MedJ 1973;42:213-22.

3 Carter CO, David PA, Laurence KM. A family study of major central nervous system malformations in South Wales. J Med Genet 1968;5:81-106.

4 Nevin NC, McDonald JR, Walby AL. A comparison of neural tube defects identified by two independent routine recording systems for congenital malformations in Northern Ireland. Int J Epidemiol 1978;7:319-21.

5 Richards IDG, McIntosh HT, Sweenie S. A genetic study of anencephaly and spina bifida in Glasgow. Dev Med Child Neurol 1972;14:626-39.

6 Williamson, EH. Incidence and family aggregation of major congenital malformations of the central nervous system. J Med Genet 1965;2:161-72.
7 Carter CO, Evans K. Spina bifida and anencephalus in Greater London. J Med Genet 1973;10:209-34.

8 Carter CO, Roberts JAF. The risk of recurrence after two children with central nervous system malformations. Lancet 1967;1 :306-8.

9 Creasy MR, Alberman ED. Congenital malformations of the central nervous system in spontaneous abortions. J Med Genet 1976;13:9-16.

10 MacHenry JCRM, Nevin NC, Merrett JD. Comparison of central nervous system malformations in spontaneous abortions in Northern Ireland and South-East England. Br Med J 1979;1:1395-7.

11 Janerich DT, Piper J. Shifting genetic patterns in anencephaly and spina bifida. $J$ Med Genet $1978 ; 15: 101-5$.

Requests for reprints to Professor N C Nevin, Department of Medical Genetics, Institute of Clinical Science, Grosvenor Road, Belfast BT12 6BJ, Northern Ireland. 